\title{
Memduh Şevket Esendal'ın eserleri üzerine bir bibliyografya denemesi
}

\section{Yasin BEYAZ1} APA: Beyaz, Y. (2019). Memduh Şevket Esendal'ın eserleri üzerine bir bibliyografya denemesi.
RumeliDE Dil ve Edebiyat Araştırmalar Dergisi, (14), 103-117. DOI: 10.2900o/rumelide.540997

\section{$\ddot{\mathbf{O z}}$}

Bibliyografyalar akademik ve özellikle de biyografi çalışmaları için önemli kaynaklardır. Bu kaynaklar sayesinde hazırlanacak ilmi eserler daha ciddi ve detaylı bir mahiyet kazanmaktadır. Türk edebiyatının en önemli hikâye yazarlarından ve hikâyeciliğimizin kilometre taşlarından biri olan Memduh Şevket Esendal hakkında bu anlamda tam ve bütünlüklü bir bibliyografya çalışması yapılmamıştır. Onun hakkında yapılan çalışmaların (diğer edebiyatçılarımız hakkında yapılanlarla mukayese ettiğimiz zaman) yok denecek kadar az olduğunu görmekteyiz. Bunda onun siyasi olarak durduğu yerin ve fikirlerinin büyük etkisi vardır. Onun fikri ve siyasi tercihleri ademiyete mahkum edilmesindeki temel etkendir. Böyle göz ardı edilen bir edebiyatçıyı tekrardan gün yüzüne çıkarmak için uzun soluklu bir çalışma gerekmektedir. Buna Esendal'ın uzun yazarlık hayatını da eklemek lazımdır. Yaklaşık yarım asırlık bir zaman dilimi içinde çeşitli siyasi ve edebi çevreler içinde yer almış, hayatının önemli bir bölümünü yurt dışında geçirmiş biri olarak onun eserlerini bir araya getirmek çok da kolay değildir. Ayrıca müstear isimler kullanarak hikâyeler kaleme alması araştırmayı biraz daha zorlaştırmaktadır. Fakat Osmanlı'dan Cumhuriyet'e neşredilmiş olan edebi dergilerle alakalı yapılan tezler bu zorlukları bir nebze de olsa kolaylaştırmıştır. Ancak gazeteler için aynı şeyleri söylemek mümkün değildir. Çünkü gazetelerin edebi yönden incelenmesi ve yazar kadrolarıla tezler dergilere nazaran zayıf kalmıştır. Buna ek olarak bazı gazete nüshalarının ve ciltlerinin bulunmaması da bu alandaki eksikliklerdendir. Bu çalışmada bütün bu olumsuzluklara rağmen Memduh Şevket Esendal'ın siyasi ve edebi çevresi dikkate alınarak dönemin süreli yayınlarının tamamına yakını taranarak onun eserlerinin bütünlüklü bir bibliyografyası ortaya konulmak istenmiştir.

Anahtar kelimeler: Memduh Şevket, bibliyografya, hikâye, Tanin gazetesi, Ulus gazetesi.

\section{An essay of bibliography on works of Memduh Şevket Esendal}

\begin{abstract}
Bibliographies are important sources for academic and especially biographical studies. Thanks to these sources, the scientific works are more serious and detailed. About Memduh Şevket Esendal, one of the most important story writers of Turkish literature and one of the milestones of our storytelling, a complete bibliography study has not been made in this sense. We can see that the studies about him (when we compare with the other writers of our literature) are really few. The place and ideas of his political standing in it has a great impact on this. His idea and political choices are the main factors condemning the decree. A long-term study is needed in order to reopen such a neglected literate. It should be added to Esendal's long life of authorship. It is not easy to put together all his works as a person who has taken part in various political and literary circles in a period of half a century and has spent a significant part of his life abroad. In addition, writing stories using
\end{abstract}

1 Dr. Öğr. Üyesi, Yalova Üniversitesi, İslami İlimler Fakültesi, Türk İslam Edebiyatı, (Yalova, Türkiye), yasinbeyaz8o@hotmail.com, ORCID ID: 0ooo-0002-9086-1458 [Makale kaylt tarihi: 16.01.2019-kabul tarihi: 12.03.2019; DOI: 10.29000/rumelide.540997] 


\begin{abstract}
pseudonyms makes research more difficult. However, the theses about the literary journals published from the Ottoman Empire to the Republic facilitated these difficulties. But it is not possible to say the same things for newspapers. Because the literary analysis of the newspapers and the author's staff and theses were weaker than journals. In addition, the absence of some newspaper copies and volumes is one of the shortcomings in this area. In this study, in the light of the political and literary environment of Memduh Şevket Esendal, despite all these problems, almost all of the periodicals of the period were screened and a complete bibliography of his works is presented.
\end{abstract}

Key words: Memduh Sevket, bibliography, story, Tanin newspaper, Ulus newspaper.

\title{
Giriş
}

Memduh Şevket ile alakalı daha önce yapılan çalışmalarda onun ilk eserinin 1908'de Tanin'de yayımlandığı ifade edilmiştir (Uyguner, 1991, s. 51/Çetişli, 2004, s. 38). Ancak onun bilinen ilk edebi yazısı "Reşaşe-i Garam" adıyla 1902'de İrtika (M. Memduh, 1318/ 1902, s. 341.) ve Musavver Fen ve Edeb (M. Memduh, 1318/1902, s. 377-378.) mecmualarında neşredilmiştir (Kolcu, 2004, s. XX, 28). Bu bağlamda Tahir Alangu ise Esendal'ın yayınlanan ilk eserinin tarihini 1900 olarak belirtmiş ancak herhangi bir detay vermemiştir. Ayrıca İrtika'daki yazısının neşir tarihini de yanlışlıkla 20 Mart 188914 Mart 1902 olarak göstermiştir (Alangu, 1968, s. 125.).

Esendal'ın ilk hikâyesiyse "Veysel Çavuş" ismiyle 1908 yllında Tanin'de yayımlanmıştır (Memduh Şevket, 1324/1908, s. 3-4.). Tanin sütunlarında "Rüyada" ve "Mevla Kavuştursun" adlı iki hikâyesi daha neşredilmiştir. Memduh Şevket'in Tanin'de hikâyeleri yanında "Kara Mehmed: Kandiye Muhasarası Vekayiinden”, "Ziraate Dair” ve "Geçen Lakırdılar” isimli yazıları da yayımlanmıştır (Beyaz, 2018, s. 123-

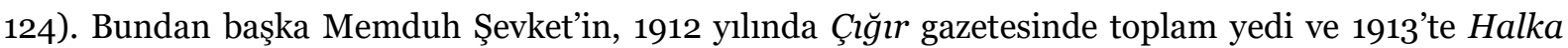
Doğru gazetesinde de bir hikâyesi mevcuttur. Yazar, bu tarihten 1924'te Meslek gazetesinde "Mülahazat Hanesi” isimli hikâyesini yayınladığı döneme kadar bir suskunluk devresi geçirmiştir. Meslek’te ise onun 35 hikâyesi Miras romanı neşredilmiştir (Çetişli, 2004, s. 40-41).

Uzun bir aradan sonra Memduh Şevket'in hikâyeleri (1930 yılında Tahran'daki büyükelçilik görevi ardından) ilkin Cumhuriyet (1931) daha sonra da Vakit (1932) gazetesi sütunlarında görülmektedir. Cumhuriyet'te toplam 12, Vakit de ise dört hikâyesi ve Ayaşh ile Kiracıları romanı tefrika edilmiştir. Bu romanın tefrikası, Kabil Büyükelçiliği görevini yürütürken yapılmış ve aynı yıl içinde kitap olarak basılmıştır (Çetişli, 2004, s. 41).

Afganistan'daki görevi sonrası ilk hikâyeleri Ülkü dergisinin sütunlarında görülmektedir. Ülkü'den sonra hikâyeleri İstanbul Kültür, Seçilmiş Hikâyeler, Pazar Postası, Türk Dili, Ulus, Hisar, Sanat ve Edebiyat Gazetesi gibi dergi ve gazetelerde yayınlanmıştır. Yazarın bu dönemde toplam 5o hikâyesi neşredilmiştir (Beyaz, 2018, s. 88-93). Memduh Şevket, hikâyelerinin bir kısmını Hikayeler I-II ismiyle 1946 yılında "Basın Kültür Kooperatifi”nde bastırmıştır. Ulus gazetesi sahibi Ahmet Selgil’in ısrarı üzerine 1948-49 yıları arasında bu gazetede hikâyeler kaleme almıştır.

Memduh Şevket'in ölümünden sonra Dost Yayınevi 1957-1958 yılları arasında Esendal'ın hikâyelerinden bazılarını Otlakçı ve Mendil Altında adıyla iki kitap halinde yayınlamıştır. Daha sonra 1965 yılında Temiz Sevgiler ve 1971'de de Ev Ona Yakışt ismiyle iki hikâye kitabını daha neşretmiştir. Aradan epey bir zaman geçtikten sonra Muzaffer Uyguner, Esendal'ın eserlerinin tamamını 1983 ylından itibaren neşretmeye başlamıştır. 


\section{Memduh Şevket Esendal'ın bibliyografyası}

Türk edebiyatının önemli isimleri arasında yer alan Memduh Şevket Esendal üç yüze yakın hikâye kaleme almıştır. Bu kadar çok hikâye yazmış olmasına rağmen göz ardı edilmekten kurtulamamış ve hakkında yapılan ilmi çalışmalar da bundan nasibini almıştır. Bu çalışma da bu alandaki eksiği bir nebze olsun kapatmak amacindadır.

Bu bibliyografya oluşturulmadan önce Meşrutiyet'in ilanından Demokrat Parti’nin iktidara geldiği döneme kadar siyasi hayatımızın kırılma noktaları ve bu kırılma noktalarında Memduh Şevket'in konumu, etrafindaki insanlar, hangi gruplarla birlikte olduğu tespit edilmiştir. Bu tespitlerden sonra siyasi ve edebi çevrelerin geçişkenliğinden faydalanılıp onun edebi faaliyetleri belirlenmiştir. Bu edebi faaliyetleri belirlerken yazarın yurtdışı görevleri de dikkate alınarak Türkiye'de bulunduğu dönemlerde birlikte olduğu çevrelerin çıkardıkları gazete ve dergiler listelenmiştir. Bütün bunların yanında döneme dair edebi ve siyasi hatıratlar da taranmıştır. En sonunda oluşturulan bu listeler çerçevesinde taramalar yapılmıştır. Bu taramalardan sonra elde edilen bilgiler şu şekilde tasnif edilmiştir:

1-Öncelikle kitap ve süreli yayınlar ayrı ayrı gruplandırılmıştır.

2-Basılan kitaplar kronolojik sıra dikkate alınarak türlerine göre tasnif edilmiştir. Roman, hikâye, anı, mektup gibi.

3-Hikâye kitapları içerisinde yer alan bütün hikâyeler okuyucu ve araştırmacıların tekrarları görmeleri için tek tek zikredilmiştir.

4-Süreli yayınların taranmasında elde edilen bilgiler de aynı şekilde edebi türler ve kronoloji dikkate alınarak tasnif edilmiştir. Hikâye, şiir, düzyazı gibi.

5-Hem kitaplarda hem de süreli yayınlarda neşredilen eserlerdeki müstear isimler de aynen bırakılmıştır.

\subsection{Kitaplar}

\subsubsection{Romanlar}

1-M.Ş., Ayaşlı ve Kiracıları, Vakit, 12 Mart-21 Mayıs 1934. (Bu roman aynı yıl Vakit matbaasında kitap olarak basılır. 1957 yılında Ayaşlı ile Kiracıları adıyla Memduh Şevket Esendal adına Dost Yayınları neşretmiştir. Kitap daha sonra 1988 yllında Bilgi Yayınevi tarafından basmıştır. Roman 1989 yllında televizyona uyarlanarak TRT 1 Kanalı’nda yayınlanmıştır. Dizinin senaristliğini Turgut Yasalar yaparken yönetmenliğini Tunca Yönder üstlenmiştir.)

2- Vassaf Bey, Ankara 1983.

3-Miras, Ankara 1988. 


\subsubsection{Hikâyeler}

1-M.Ş.E., Hikâyeler I², Ankara 1946 (Gençlik, Kayışı Çeken, Arabacı Ali, Bir Eğlenti, Otlakçı, Döğüş, Mülahazat Hanesi, Köye Düşmüş, Bir Kadının Mektubu, İki Kadın, Pazarlık, İki Ana İki Kız, Türbe, Hüseyin Bey'in Sakalı, Söylüyor, Deli, Yirmi Kuruş, Bildim, Seni Kahve Paklar, En Ona Yakıştı, Asılsız Bir Sözün Esası, Eşek, Hastanenin Yemek Tablası, Düğün Dönüşü, İşin Bitti).

2- M.Ş.E., Hikâyeler II ${ }^{3}$, Ankara 1946 (Avni Hurufi Efendi, El Malının Tasası, İki Ziyaret, Rüya Nasıl Çıktı?, Ana Baba, Şair Tavafi, Haşmet Gülkokan, Keleş, Hasta, Gevenli Hacı, Mendil Altında, Feminist, Düğün, Müdürün Züğürdü, Karga Yavrusu, Kızımız, Gül Hanım’ın Annesi, Sinema, Kaçırdık mı?, Kuvvetli Hükümet, Saide, Dursun Hacı, Celile, İhtiyarlık, Hayat Ne Tatlı).

3-Otlakçı, Dost Kitabevi, Ankara 1958 (Gençlik, Kayışı Çeken, Arabacı Ali, Bir Eğlenti, Otlakçı, Dö̆̆üş, Mülahazat Hanesi, Köye Düşmüş, Bir Kadının Mektubu, İki Kadın, Pazarlık, İki Ana İki Kız, Türbe, Haydar Bey’in Sakalı, Söylüyor, Deli, Yirmi Kuruş, Bildim, Seni Kahve Paklar, Ev Ona Yakıştı, Asılsız Bir Sözün Esası, Eşek, Hastanenin Yemek Tablası, Düğün Dönüşü, İşin Bitti).

4-Esendal, Temiz Sevgiler, Dost Kitabevi, Ankara 1965 (İane, Bir Mübahase, Hasta, Mebus Olursa, Yirmi Kuruş, Mülahazat Hanesi, Otlakçı, İşin Bitti, Dedikler, Şimdilik Dursun, Kayışı Çeken, Köye Düşmüş, Avrupa, Çölde, Eşek, Hayat Ne Tatll, Gençlik, Çaya Giderken, Seni Kahve Paklar, Dügün, Müdürün Züğürdü, Aptal Sen de, Tövbeler Olsun, Pazarlık, Bir Eğlenti, Bildim, Traş, Temiz Sevgiler, Deli, Mendil Altında, Keleş, Ölü, Feminist).

5-Esendal, Ev Ona Yakıştı, Dost Kitabevi, Ankara 1971 (Uğursuzluk, Bir Mektup ve Cevabı, İhtiyar Kadın, İki Kadın I, İki Kadın II, Gevenli Hacı, Avni Hurufi Efendi, Kuvvetli Hükümet, Hastanenin Yemek Tablosu, Sinema, Ana Kız-İki Kız, Haydar Bey’in Sakalı, Gül Hanım’ın Annesi, İki Ziyaret, Asılsız Bir Sözün Esası, Arabacı Ali, Kaçırdık mı?, Düğün Dönüşü, Kızımız, Haşmet Gülkokan, Celile, Bir Kadının Mektubu, Türbe, Ev Ona Yakıştı, Ana-Baba, Rüya Nasıl Çıktı, İhtiyarlık, Doğuş, Karga Yavrusu, Dursun Hacı, Bir Akşam Üstü, Sahan Külbastısı, Kurt Masalı, Bu Yollar Uzar, Karısının Kocası).

6-Resquilleur:Nouvelles Choisies, Tercüme; Tahsin Saraç, Imprimerie de L'education Nationale, İstanbul 1971.

7- Mendil Altında, Bilgi Yayınevi, Ankara 1983 (Avni Hurufi Efendi, El Malının Tasası, İki Ziyaret, Rüya Nasıl Çıktı, Ana Baba, Şair Tavafi, Haşmet Gülkokan, Keleş, Hasta, Gevenli Hacı, Mendil Altında, Feminist, Düğün, Müdürün Züğürdü, Karga Yavrusu, Kızımız, Gül Hanım’nn Annesi, Sinema, Kaçırdık mı?, Kuvvetli Hükümet, Sacide, Dursun Hacı, Celile, İhtiyarlık, Hayat Ne Tatlı).

8- Sahan Külbastısı, Bilgi Yayınevi, Ankara 1983 (İane, Bir Mübahase, Mebus Olursa, Dedikler, Şimdilik Dursun, İnsafsız, Avrupa, Çölde, Çaya Giderken, Aptal Sende!, Tövbeler Olsun, Uğursuzluk, İhtiyar Kadın, Bir Akşamüstü, Sahan Külbastısı, Kurt Masalı, Bu Yollar Uzar, Karısının Kocası, Mevla Kavuştursun, Hasan Kahya Hastalandı, Bir Mektup, Büyükbaba, Sabuncu Osman Ağa, Şefika'nın Hanımları).

9- Veysel Çavuş, Bilgi Yayınevi, Ankara 1984 (Veysel Çavuş, Kivi, Seza’nın Kocası, Pazarcılık, Bir Genç Efendinin Defterinden, Bir Cinayet, Gurbet Ellerinde, Sayı mı, Yazı mı?, Hamid İçin Bir Yazı, Komiser,

$2 \quad$ Hikayeler I kitabı daha sonra Dost Yayınları tarafından 1958 yılında Otlakçı ismiyle basılmıştır.

3 Bu kitap daha sonra Bilgi Yayınları tarafından Mendil Altında ismiyle yayınlanmıștır. 
Taş Havan, İki Arkadaş, Yeni Vali, Ev Kurdular, Türk Dursun, Bayan Nazmiye, Artist Olacak Kız, Bir Genç, Haham, Bir Evlenme, Sefer Kalfaların Hüseyin, Hanende Hayım, Dedikodu, İntizam, Muzaffer).

10- Bir Kucak Çiçek, Bilgi Yayınevi, Ankara 1984 (Anlaşılmamış Bir Nokta, Güzel Bir Ölüm, Bir Haydut Kuş, Şu Soyadı Konusu, Küp Kırığı Pabuç Eskisi, Geçmiş Günler, Yol Arkadaşları, Doktor Savdur, Gezide, Bir Kucak Çiçek, Aptal Memiş, Kedi, Terbiyesi En Güç Hayvan, Hatice, İşin Dibi Bozulmuş, Hırsızlık, Tutkunluk, Adım, Bana Kaçık Derler, Santa Kastello, Nazırın Odacısı, Gece Kuşu, Buğday Almaya Köye Gitmiştik, Konuşma, Turan Hanım).

11- İhtiyar Çilingir, Bilgi Yayınevi, Ankara 1984 (İkisinin Arasında, Korku, Bomba, Arkadaşım, Hürriyet Gelirken, Eyüpsultan Yolcusu, Altınbalıkları, Vakitsiz Bir Ezan, İhtiyar Çilingir, Bozdayı, Otomobilin Hızı, Ankara'daki Kiralık Ev, Hacı İzzet Paşa, Monte Nuvare Belediye Başkanı, Hacı Dedemin Evi, Postacı Halit, Acı Geçer Sızı Kalır, Bu Sıska Karı, Hafız, Halkevine Bir Adam, Sorumlu, Büyük Yanlış, Bekir Usta, Rüştiye, Bay Özarıer).

12- Hava Parası, Bilgi Yayınevi, Ankara 1984 (Kendini Denize At/Çamaşırcı Kadının Öksüzü, Çamaşırcı Kadın, Ahmet Besim Efendi, Murat Ali, Çolak, Hamamcı Feyzi Bey, Otelci Hacı, Arife, Mihrişah, Kerim Bey, Bir Mektuptan, Patron, Hava Parası ${ }^{4}$, Avarakasnak, Casusluk, Mumuşcuğum, Yarı Ölü, Randıman, Dışı Başka İçi Başka, Hayım’ın Evi, İlaç İçirmek İçin, Demiryolu Durağında Bir Baraka, Bir Kadın, Monte Reale Belediye Başkanı, Gizli Acı).

13- Bizim Nesibe, Bilgi Yayınevi, Ankara 1985 (Bizim Nesibe, Eski Kına Gecesi, İstanbul'da Bir Bayram Gününün Hikâyesi, Gurbetten Dönerken, Tuzcuoğlu'nun Otçuluğu, Kardeş Çocukları, Nebiye'nin Kasabasında Hayat, Kısmet Kuşu, Anasız Çocuk, Kaşıkaraoğlu, Bir Çocuğun Hikâyesi, Garip Bilgisizler Alayı, Büyük Ana, Ahmet Paşa'nın Katli, Kaptan Boryat).

14- Kelepir, Bilgi Yayınevi, Ankara 1986 (Behiye, Kelepir, İç Acısı, Ölüler Hikâyesi, Ayşe'nin Kocası, Çocuklara Hikâye, O Yıllarda, Hanife, Falanca Bey, Yusuf Koçoğlu, Akşam Yemeğinden Sonra, Çamur Ahmet'in Çıkışları, Ayhan, Cami Duvarı Kenarında, Berrin'in Evliliği, Çocukluk, Behiye, Kelepir, İç Acısı, Ölüler Hikâyesi, Ayşe'nin Kocası, Çocuklara Hikâye, O Yıllarda, Hanife, Falanca Bey, Yusuf Koçoğlu, Akşam Yemeğinden Sonra, Çamur Ahmet’in Çıkışları, Ayhan, Cami Duvarı Kenarında, Berrin’in Evliliği).

15- Gödeli Mehmet, Bilgi Yayınevi, Ankara 1988 (Gödeli Mehmet, Bayram Günleri, Çamlıca'daki Konak, Baba Halil, Büyük Hızır Bey Konă̆ı, Rüstem Ağa’nın Oğlu, Nazlı Hanım, Sevdiğim, İnsanın Ben’i, Soysuz Kedi, İki Müsteşar, Demokratik Seçimler, Bir Nutuk, Alemşah Mahallesi, Bir Aile Hayatı Üzerine Etüd, Centilmen Asilzadeler Pansiyonu, Mesut Bacı, Yurda Dönüşš).

16- Güllüce Bağları Yolunda, Bilgi Yayınevi, Ankara 1988 (Adnan'la Karısı, Başarılar, Enaristan, Güllüce Bağları Yolunda, Hayata Başlarken, Karşılama Töreni, Karşılık, Kayaş’ta, Seyyit Battal, Sokakta, Tipide Yolculuk, Yol ve Işık Birliği).

17- Gönül Kaçanı Kovalar, Bilgi Yayınevi, Ankara 1993 (Arkadaş Konuşuyor, Bayan Nermin, Bir Baba Oğul, Bir Karı Koca, Borç Alma Usulü, Çocukluk, Evdeki Hesaplar, Gönül Kaçanı Kovalar, İsmail Sabih

\footnotetext{
$4 \quad$ Anladığımız kadarıyla bu hikaye İkinci Dünya Savaşı yıllarında yazılmış olmalıdır. Çünkü Münevver Ayaşlı’nın anlattı̆̆ına göre bu yıllarda en çok kullanılan kelimelerden birisi de "hava parası"dır. (Bkz. Ayaşlı, 2016, s. 207. ) Bu konu için ayrıca Bkz. Adivar, 2016, s. 116

$5 \quad$ Bu hikayenin ilk ismi “Doktor Sınırı Nasıl Geçti”dir. (Bkz. Esendal, 2003, s. 154.)
} 
Bey'in Gazetesi, İsmet Hanım, İstasyon Yolu, Kız Arkadaşlar, Müfettişe Oyun, Örnek Kız, Palavra, Paşa'nın Gözü Memur Görsün, Perinur'un Hayalleri, Propaganda, Sıdıka, Sinir Doktoru, Sofu Adamın Kızı, Tirazizade Sadullah Efendi Konağı).

18- Mutlu Bir Son, Bilgi Yayınevi, Ankara 2005 (Asker Hekimi, Banka Müdürüne Mektup, Bir Şef, Filantrop, İltimas, Hafız Hanım, Donna Alvonza’nın Söylevi, Bizim Müşavir Bey, Sabah Dedikodusu, Genç Kızla Yaşlı Adam, Kira Pazarlığı, Bankacı Rasim Bey, Berber Kalfası, Binnaz Enver Hanım’ın Çayları ve Kocası, Banyoda Kalan Adam, Çürük Yürekli, Şeytan, Babam Evlendi, Ağzım Çirkin, Kocası Ölen Kadın, Hakimi Sinirlendiren Avukat, Umulmazlıklar, Arkadaşlık, Evlenelim mi?, Evde Sabah, Yalnız Adam, Şehirden Köye, Herşey Kendi Dekoru İçinde, Gece Kulübünde, Müdür Yardımcımız, Göç Başlıyor, Bayan İçtürk, Vezir Kızı, Dulca'nın Başı Belada, Bayan Servet’in Kısa Hikâyesi, Amcaoğulları, Uçak Nasıl Uçar, Kızı Dağa Kaldırmışlar, Düşünüş, Kadının Düşleri, Bitmeyen Senaryo, Bebekler, Evlendik, Mutlu Bir Son, Perihan'ın Nişanlısı, Suçlu, Toy Çocuk, Uzak Bir Ülke, Kundura Boyacısı, Babayla Kızı).

19- Bir Haydut Kuş, Bilgi Yayınevi, Ankara 2005 (Bir Haydut Kuş, Eşek, O Yıllarda, Çocukluk, Kendini Denize At, Hacı Dedemin Evi, Ana Baba, Karga Yavrusu, Gül Hanım’ın Annesi, Kivi, Dövüş).

\subsubsection{Mektuplar}

1- Kızıma Mektuplar, Bilgi Yayınevi, Ankara 2001.

2- Oğullarma Mektuplar, Bilgi Yayınevi, Ankara 2003.

\subsubsection{Anılar}

1- Tahran Anıları ve Düşsel Yazılar, Bilgi Yayınevi, Ankara 1999. (Çorlu'nun İnsanları, Yaramaz Çocuk, Ağaçkakan Kuşu ve Başkaları, Hafız Hanım’dan Masal, Geçmiş Yüzyıllarda Yolculuk, Öte Dünyada)

\subsection{Dergi ve gazeteler}

\subsection{1. Şiir}

1-M. Memduh, (Mensur Şiir) “Reşaşe-i Garam”, Musavver Fen ve Edeb Mecmuası, nr. 147, o8 Ağustos 1318/21 Ağustos 1902, s. 377-378.

2- M. Memduh, (Mensur Şiir) “Reşaşe-i Garam”, İrtika, nr. 188, 25 Teşrin-i Evvel 1318/8 Teşrin-i Sani 1902, s. 377-378.

\subsubsection{Düzyazı}

1-Memduh Şevket, (Tarih) Sahâif-i Tarihten: Kara Mehmed-Kandiye Muhasarası Vekayiinden” (Raşid Tarihi’nin birinci cildinden alıntı yapmıştır.), Tanin, 13 Şubat 1324 (1909), Numara 206, s. 4.

2-Memduh Şevket, Ziraate Dair, Tanin, 5 Teşrin-i Sani 1909, s. 1-2.

3-M.Ş., "İlk Gençlik”, Kitabiyât (İbrahim Alaaddin’in Kitabı Üzerine), Hayat Mecmuası, 17 Mart 1927, sayl 16, s. 16. 
4-M. Şevket, Karagümrük İman Yurdunda, Vakit ${ }^{6}$, 1Temmuz 1931.

5-M. Şevket, Karagümrük Kulübünden Recai Bey’e Göre, Vakit, 29Temmuz 1931.

6-M. Şevket, Bir Tuzgun, Vakit, 13 Ağustos 1931.

7-M. Şevket, Yerli Mallar Sergisi ve Genç Terzi (Yarenlik), Vakit, 19Ağustos 1931.

8- Mustafa Yalınkat, “Karadeniz” (Yarenlik), Ülkü, sayı 103, 1 Ocak 1946, s. 18-20.

\subsubsection{Hikâye}

1-Memduh Şevket, (Hikâye) Veysel Çavuş, Tanin, 4 Kanuni Evvel 1324 (1908), Numara 137, s. 3-4.

2-Memduh Şevket, (Hikâye) Rüyada, Tanin, 10 Teşrin-i Evvel 1909, s. 1-2.

3- Memduh Şevket, (Musahabe), Geçen Lakırdılar, Tanin, Numara 491, 3 Muharrem 1328-15 Kanunisani 1910, s. 2.

4-Memduh Şevket, (Musahabe), Geçen Lakırdılar, Tanin, Numara 505, 17 Muharrem 1328-29 Kanunisani 1910, s. 2.

5- Memduh Şevket, (Hikâye) Mevla Kavuştursun 1, Tanin, Numara 568, 21 Rebülevvel 1328-2 Nisan 1910, s. 3 .

6-Memduh Şevket, (Hikâye) Mevla Kavuştursun 2, Tanin, Numara 570, 23 Rebülevvel 1328-4 Nisan 1910, s. 3 .

7- Memduh Şevket, (Hikâye) Mevla Kavuştursun 3, Tanin, Numara 571, 24 Rebülevvel 1328-5 Nisan 1910, s. 3 .

8-Memduh Şevket, İkisinin Arasında (Hikâye), Çığır, sayı 39, 13 Kanun-i Sani 1327/27 Ocak 1912, s. 3. 9-Memduh Şevket, Korku (Hikâye), Çığır, sayı 47, 21 Kanun-i Sani 1327/3 Şubat 1912, s. 3.

10-Memduh Şevket, Bomba (Hikâye), Çı̆̆ır, sayı 54, 28 Kanun-i Sani 1327/10 Şubat 1912, s. 2-3.

11-Memduh Şevket, Arkadaşım (Hikâye), Çı̆̆ır, sayı 6o, 4 Şubat 1327/17 Şubat 1912, s. 2-3.

12-Memduh Şevket, Hürriyet Gelirken (Hikâye), Çığır, sayı 68, 11 Şubat 1327/24 Şubat 1912, s. 2-3.

13-Memduh Şevket, Eyüp Sultan Yolcusu (Hikâye), Çığır, sayı 75, 18 Şubat 1327/3 Mart 1912, s. 2-3.

14-Memduh Şevket, Altın Balıkları (Hikâye), Çı̆̆ır, sayı 82, 25 Şubat 1327/10 Mart 1912, s. 2-3.

15-M.Ş., (Hikâye) Gödeli Mehmed, Halka Doğru, sayı 4, 2 Mayıs 1329/16 Mayıs 1913, s. 26-29.

\footnotetext{
6 Memduh Şevket Esendal'ın ismi 1930'lu yıllarda Vakit gazetesi muhabirleri arasında zikredilmektedir. (Bkz. Türkarslan, 2011, s. 25.) 
16-M.Ş., "Küçük Hikâye: Mülahazat Hanesi," Meslek, sayı 1, 15 Kanûnıevvel -Aralık 1924, s. 10- 12 17-M.Ş., "Küçük Hikâye: Otlakçı," Meslek, sayı 2, 23 Kanûnıevvel -Aralık 1924, s. 12 18-Mustafa Memduh, (Roman) Miras, Meslek, 1924, sayı 1-38. (Bu roman 1988 yılında Bilgi Yayınevi tarafından Memduh Şevket Esendal ismiyle neşredilmiştir.)

19-M.Ş., "Küçük Hikâye: İşin Bitti," Meslek, sayı 3, 30 Kanûnıvvel -Aralık 1924, s. 9-10

20-M.Ş., "Küçük Hikâye: Beş Bin Olsun," Meslek, sayı 4, 6 Kanûnısânî - Ocak 1925, s. 14

21-M.Ş., “Küçük Hikâye: Müdürün Derdi,” Meslek, sayı 5, 13 Kanunisani-Ocak 1925, s. 13.

22-M.Ş., "Küçük Hikâye: İnsafsız," Meslek, sayı 6, 20 Kanûnısânî - Ocak 1925, s. 13

23-M.Ş., “Küçük Hikâye: Aptal; Sen de:”, Meslek, sayı 7, 27 Kanûnısânî - Ocak 1925, s. 14

24-M.Ş., "Küçük Hikâye: Bir Eğlenti Alemi," Meslek, sayı 8, 3 Şubat 1925, s. 13

25-M.Ş., "Küçük Hikâye: Bir Eğlenti Alemi," Meslek, sayı 9, 10 Şubat 1925, s. 14

26-M.Ş., "Küçük Hikâye: Tövbeler Olsun," Meslek, sayı 10, 17 Şubat 1925, s. 14

27-M.Ş., "Küçük Hikâye: “Dedik”ler," Meslek, sayı 11, 24 Şubat 1925, s. 13

28-M.Ş., "Küçük Hikâye: Mebus Olursa," Meslek, sayı 12, 3 Mart 1925, s. 14

29-M.Ş., "Küçük Hikâye: Sabırsız," Meslek, sayı 13, 10 Mart 1925, s. 14

30-M.Ş., "Küçük Hikâye: İane," Meslek, sayl 14, 17 Mart 1925, s. 13-14

31-M.Ş., "Küçük Hikâye: Konferans,"7 Meslek, sayı 15, 24Mart 1925, s. 12

32-M.Ş., "Küçük Hikâye: Vapur Davası,"8 Meslek, sayı 16, 31 Mart 1925, s. 14

33-M.Ş., "Küçük Hikâye: Enver Efendi," Meslek, sayı 17, 7 Nisan 1925, s. 13

34-M.Ş., "Küçük Hikâye: Şimdilik dursun!," Meslek, sayı 18, 14 Nisan 1925, s. 13

35-M.Ş., "Küçük Hikâye: Bir hasbihal," Meslek, sayı 19, 21 Nisan 1925, s. 13

36-M.Ş., "Küçük Hikâye: Hastalık," Meslek, sayı 20, 28 Nisan 1925, s. 13-14

37- M.Ş., "Küçük Hikâye: Hafız," Meslek, sayı 21, 5 Mayıs 1925, s. 13

38-M.Ş., "Küçük Hikâye: Hayat Ne Tatlı," Meslek, sayı 22, 12 Mayıs 1925, s. 14

$7 \quad$ Bu hikaye Hikayeler I de Söylüyor ismiyle Temiz Sevgiler adlı kitapta da Trraş ismiyle neşredilmiştir.

$8 \quad$ Bu hikaye Hikayeler II'de El Malının Tasası ismiyle Temiz Sevgiler adlı kitapta da Temiz Sevgiler ismiyle neşredilmiştir. 
39-M.Ş., "Küçük Hikâye: Avrupa,", Meslek, sayı 23, 19 Mayıs 1925, s. 13

40-M.Ş., "Küçük Hikâye: Bir Memuriyet Meselesi," Meslek, sayı 24, 26 Mayıs 1925, s. 14- 15

41-M.Ş., "Küçük Hikâye: Köye Düşmüş," Meslek, sayı 25, 2 Haziran 1925, s. 13-14

42-M.Ş., "Küçük Hikâye: Feminist”, Meslek, sayı 26, 9 Haziran 1925, S. 13

43-M.Ş., "Küçük Hikâye: Gençlik," Meslek, sayı 27, 16 Haziran 1925, s. 13

44-M.Ş., "Küçük Hikâye: Çaya Giderken," Meslek, sayı 28, 23 Haziran 1925, s. 12125

45-M.Ş., "Küçük Hikâye: Yirmi Kuruş," Meslek, sayı 29, 30 Haziran 1925, s. 11-12

46-M.Ş., "Küçük Hikâye: Ölü," Meslek, sayı 30, 7 Temmuz 1925, s. 13

47-M.Ş., "Küçük Hikâye: Düğünde," Meslek, sayı 31, 14 Temmuz 1925, s. 13

48-M.Ş., "Küçük Hikâye: Keleş," Meslek, sayı 32, 21 Temmuz 1925, s. 12

49-M.Ş., "Küçük Hikâye: Bir Muhasebe," Meslek, sayı 33, 28 Temmuz 1925, s. 13

50-M.Ş., "Küçük Hikâye: Eşek," Meslek, sayı 34, 4 Ağustos 1925, s. 12

51-M.Ş., "Küçük Hikâye: Çölde," Meslek, sayı 35, 11 Ağustos 1925, s. 17

52-M.Ş., "Küçük Hikâye: Uğursuzluk," Meslek, sayı 37, 25 Ağustos 1925, s. 11-12

53-M.Ş., Sinema (Hikâye), Cumhuriyet, 1 Kanun-i Evvel 1931, s. 4.

54- M.Ş., Sinema (Hikâye), Cumhuriyet, 2 Kanun-i Evvel 1931, s. 4.

55- M.Ş., Sinema (Hikâye), Cumhuriyet, 3 Kanun-i Evvel 1931, s. 4.

56- M.Ş., Türbe (Hikâye), Cumhuriyet, 3 Teşrin-i Sani 1931, s. 4.

57- M.Ş., İhtiyar Kadın (Hikâye), Cumhuriyet, 4 Teşrin-i Sani 1931, s. 4.

58- M.Ş., Gül Hanımın Annesi (Hikâye), Cumhuriyet, 5 Teşrin-i Sani 1931, s. 4.

58- M.Ş., Bir Çift Ana Kız (Hikâye), Cumhuriyet, 6 Teşrin-i Sani 1931, s. 4.

60- M.Ş., Ecel... (Hikâye), Cumhuriyet, 7 Teşrin-i Sani 1931, s. 4.

61- M.Ş., Kaçırdık mı? (Hikâye), Cumhuriyet, 8 Teşrin-i Sani 1931, s. 4.

62- M.Ş., Asılsız Bir Sözün Esası (Hikâye), Cumhuriyet, 9 Teşrin-i Sani 1931, s. 4.

63- M.Ş., Düello (Hikâye), Cumhuriyet, 11 Teşrin-i Sani 1931, s. 4. 
64- M.Ş., Kuvvetli Hükümet (Hikâye), Cumhuriyet, 14 Teşrin-i Sani 1931, s. 4. 65- M.Ş., Kuvvetli Hükümet (Hikâye), Cumhuriyet, 15 Teşrin-i Sani 1931, s. 4. 66- M.Ş., Kuvvetli Hükümet (Hikâye), Cumhuriyet, 17 Teşrin-i Sani 1931, s. 4. 67- M.Ş., Kuvvetli Hükümet (Hikâye), Cumhuriyet, 18 Teşrin-i Sani 1931, s. 4. 68- M.Ş., Kuvvetli Hükümet (Hikâye), Cumhuriyet, 19 Teşrin-i Sani 1931, s. 4. 69- M.Ş., İki Ziyaret (Hikâye), Cumhuriyet, 20 Teşrin-i Sani 1931, s. 4. 70- M.Ş., İki Ziyaret (Hikâye), Cumhuriyet, 21 Teşrin-i Sani 1931, s. 4. 71- M.Ş., İki Ziyaret (Hikâye), Cumhuriyet, 22 Teşrin-i Sani 1931, s. 4. 72- M.Ş., İki Ziyaret (Hikâye), Cumhuriyet, 24 Teşrin-i Sani 1931, s. 4. 73- M.Ş., İki Ziyaret (Hikâye), Cumhuriyet, 25 Teşrin-i Sani 1931, s. 4. 74- M.Ş., İki Ziyaret (Hikâye), Cumhuriyet, 26 Teşrin-i Sani 1931, s. 4. 75- M.Ş., İki Ziyaret (Hikâye), Cumhuriyet, 27 Teşrin-i Sani 1931, s. 4. 76- M.Ş., İki Ziyaret (Hikâye), Cumhuriyet, 28 Teşrin-i Sani 1931, s. 4. 77- M.Ş., Hastanenin Yemek Tablası (Hikâye), Cumhuriyet, 29 Teşrin-i Sani 1931, s. 4. 78- M.Ş., Hastanenin Yemek Tablası (Hikâye), Cumhuriyet, 30 Teşrin-i Sani 1931, s. 4. 79-M.Ş., "Bir Mektup ve... Cevabı 1” (Küçük Roman), Vakit, 24 Ağustos 1932, s. 5. 80-M.Ş., "Bir Mektup ve... Cevabı 2" (Küçük Roman), Vakit, 25 Ağustos 1932, s. 5. 81-M.Ş., "Bir Mektup ve... Cevabı 3” (Küçük Roman), Vakit, 26 Ağustos 1932, s. 5. 82-M.Ş., "Bir Mektup ve... Cevabı 4" (Küçük Roman), Vakit, 27 Ağustos 1932, s. 5. 83-M.Ş., "Bir Mektup ve... Cevabı 5” (Küçük Roman), Vakit, 28 Ağustos 1932, s. 5 . 84-M.Ş., "Bir Mektup ve... Cevabı 6" (Küçük Roman), Vakit, 29 Ağustos 1932, s. 5. 85-M.Ş., "Bir Mektup ve... Cevabı 7” (Küçük Roman), Vakit, 30 Ağustos 1932, s. 5. 86-M.Ş., “Bir Mektup ve... Cevabı 8” (Küçük Roman), Vakit, 1 Eylül 1932, s. 5. 87- M.Ş., “Bir Mektup ve... Cevabı 9” (Küçük Roman), Vakit, 2 Eylül 1932, s. 5. 88- M.Ş., "Bir Mektup ve... Cevabı 10” (Küçük Roman), Vakit, 3 Eylül 1932, s. 5. 
89- M.Ş., “Bir Mektup ve... Cevabı 11” (Küçük Roman), Vakit, 4 Eylül 1932, s. 5.

90- M.Ş., “Bir Mektup ve... Cevabı 8” (Küçük Roman), Vakit, 1 Eylül 1932, s. 5.

91-M.Ş., “İhtiyarlık” (Hikâye), Vakit, 5 Eylül 1932, s. 8.

92- M.Ş., “Ana Baba”9 (Hikâye), Vakit, 13 Eylül 1932, s. 10.

93- M.Ş., “Rüya Nasıl Çıktı” (Hikâye), Vakit, 24 Eylül 1932, s. 10.

94-M.Ş.E, “Kızımız” (Hikâye), Ülkü, sayı 8, 16 İkinci Kanun 1942, s. 16-18.

95-M.Ş.E, “Ayhan” (Hikâye), Ülkü, sayı 10, 1616 Şubat 1942.

96-M.Ş.E, "Celile” (Hikâye), Ülkü, sayı 13, 1 Nisan 1942, s. 18-20.

97- M.Ş.E, “İki Kadın I” (Hikâye), Ülkü, sayı 14, 16 Nisan 1942, s. 19-20.

98- M.Ş.E, “İki Kadın II” (Hikâye), Ülkü, sayı 15, 1 Mayıs 1942, s. 23-26.

99- İstemenoğlu, “Ev Ona Yakıştı”ıo (Hikâye), Ülkü, sayı 100, 16 Kasım 1945, s. 20-21.

100-M. Oğulcuk, "Bu Yollar Uzar” (Hikâye), Seçilmiş Hikâyeler, sayı 1, 1947, s. 35-38.

101-M. Oğulcuk, "Kurt Masalı ” (Hikâye), Seçilmiş Hikâyeler, sayı 3, 3 Ekim 1947, s. 35-38.

102-Mustafa Yalınkat, "Bir Akşam Üstü” (Hikâye), Sanat ve Edebiyat Gazetesi, sayı 1, 4 Ocak 1947.

103-Mustafa Yalınkat, "Sahan Külbastısı" (Hikâye), Sanat ve Edebiyat Gazetesi, sayı 7, 15 Şubat 1947.

104-Mustafa Yalınkat, "Geçmiş Günlerden Notlar” (Hikâye), Sanat ve Edebiyat Gazetesi, sayı 27-28, 12 Temmuz 1947.

105-M.Ş.E., "Karısının Kocası"11 (Hikâye), Ulus, 14 Kasım 1948, s. 4.

106-M.Ş.E., Gizli Acı (Hikâye), Ulus, 21 Kasım 1948, s. 4.

107-M.Ş.E., Hamid İçin Bir Yazı (Hikâye), Ulus, 5 Aralık 1948, s. 4-6.

108-M.Ş.E., Bizim Nesibe (Hikâye), Ulus, 12 Aralık 1948, s. 4-5.

109-M.Ş.E., İstanbul'da Bir Bayram Günün Hikâyesi (Hikâye), Ulus, 19 Aralık 1948, s. 4.

110-M.Ş.E., Tuzcuoğlunun Otçuluğu (Hikâye), Ulus, 26 Aralık 1948, s. 4.

\footnotetext{
$9 \quad$ Kerim Yund'un ifadelerine göre Memduh Şevket Esendal bu hikayeye ilkin "Lamba Şişesi” ismin vermeyi düşünmüştür. (Bkz. Yund, 1972, s. 239) Memduh Şevket'in oğlu Ahmed Esendal bu hikayede lambanın şişesini kıran çocuğun kendisi olduğunu söyler. (Bkz. Esendal, 1972, s. 427)

10 Bu hikaye daha sonra Tülay Ertalay yönetmenliğinde TRT yapımı olarak sinemaya uyarlanmıştır.

$11 \quad$ Bu hikayenin adının aslında İhtiyar olacağını söyler. (Bkz. Esendal, 2001, s. 539.) 
111-M.Ş.E., Güllüce Bağları Yollarında (Hikâye), Ulus, 2 Ocak 1949, s. 4.

112-M.Ş.E., Kısmet Kuşu (Hikâye), Ulus, 9 Ocak 1949, s. 4.

113-M.Ş.E., Komiser (Hikâye), Ulus, 23 Ocak 1949, s. 4.

114-M.Ş.E., Çocukluk (Hikâye), Ulus, 30 Ocak 1949, s. 4.

115-M.Ş.E., Büyük Ana (Hikâye), Ulus, 6 Şubat 1949, s. 4.

116-M.Ş.E., Geçmiş Günler (Hikâye), Ulus, 13 Şubat 1949, s. 4.

117-M.Ş.E., Hacı Dedemin Evi (Hikâye), Ulus, 20 Şubat 1949, s. 4.

118-M.Ş.E., Postacı Halit (Hikâye), Ulus, 27 Şubat 1949, s. 4.

119-M.Ş.E., Karşılama Töreni (Hikâye), Ulus, 6 Mart 1949, s. 4.

120-M.Ş.E., Acı Geçer Sızı Kalır (Hikâye), Ulus, 13 Mart 1949, s. 4.

121-M.Ş.E., Yol Arkadaşları (Hikâye), Ulus, 20 Mart 1949, s. 4.

122-M.Ş.E., Taş Havan (Hikâye), Ulus, 27 Mart 1949, s. 4.

123- MEŞE, “Halkevine Bir Adam” (Hikâye), Ülkü, sayı 27, Mart 1949, s. 12-15.

124-M.Ş.E., İki Arkadaş (Hikâye), Ulus, 3 Nisan 1949, s. 4.

125-M.Ş.E., Doktor Savdur (Hikâye), Ulus, 10 Nisan 1949, s. 4.

126-M.Ş.E., Bir Siska Karı (Hikâye), Ulus, 17 Nisan 1949, s. 4.

127-M.Ş.E., Kelepir (Hikâye), Ulus, 24 Nisan 1949, s. 4.

128-M.Ş.E., Karşıllk (Hikâye), Ulus, 1 Mayıs 1949, s. 4.

129-M.Ş.E., Hafız (Hikâye), Ulus, 8 Mayıs 1949, s. 4.

130-M.Ş.E., Gezide (Hikâye), Ulus, 29 Mayıs 1949, s. 4.

131-M.Ş.E., Bir Kucak Çiçek (Hikâye), Ulus, 5 Haziran 1949, s. 4.

132-M.Ş.E., Yeni Vali (Hikâye), Ulus, 19 Haziran 1949, s. 4.

133-M.Ş.E., Kedi (Hikâye), Ulus, 26 Haziran 1949, s. 4.

134-M.Ş.E., Büyük Yanlış (Hikâye), Ulus, 3 Temmuz 1949, s. 4.

135-M.Ş.E., "Bir Kucak Çiçek” (Hikâye), Ülkü, sayı 31, Temmuz 1949, s. $17-19$. 
136-M. Ş. E., “Komiser” (Hikâye), Seçilmiş Hikâyeler, sayı 20-21, 1949, s. 11-19.

137-M. Ş. E., “Çocukluk” (Hikâye), Seçilmiş Hikâyeler, sayı 24-25, 1949, s. 15-23.

138-M.Ş.E., Ev Kurdular (Hikâye), Hisar, 1 Haziran 1950, sayı 4, s. 6-8.

139-M. Ş. E., "Hanife” (Hikâye), Pazar Postası, 4 Şubat 1951, sayı 1, s. 6-8.

140- M. Ş. E., "Bekir Usta” (Hikâye), Pazar Postası, 11 Mart 1951, sayı 6, s. 9.

141- M. Ş. E., "Rüştiye” (Hikâye), Türk Dili, C.1, S.1, Ekim 1951, s.9-16 .

142- M. Ş. E., "Bekir Usta” (Hikâye), Pazar Postası, 8 Nisan 1951, sayı 10, s. 9.

143- Memduh Şevket Esendal, "Hayat Ne Tatlı (Hikâye), Ulus, 18 Mayıs 1952, s. 2.

144- M. Ş. E., "Haydar Bey’in Sakalı" (Hikâye), Pazar Postası, 25 Mayıs 1952, sayı 68, s. 5-9.

145- M. Ş. E., “El Malının Tasası” (Hikâye),, Türk Dili, C.1, S.10, Temmuz 1952, s. 592-595.

146- M. Ş. E., “Geçmiş Günler” (Hikâye), Seçilmiş Hikâyeler, sayı 8, Eylül 1952, s. 10-13.

147-M. Ş. E., "Postacı Halit” (Hikâye), Seçilmiş Hikâyeler, sayı 9, Ekim 1952, s. 18-22.

148- M. Ş. E., "Tuzcuoğlunun Otculuğu” (Hikâye), Seçilmiş Hikâyeler, sayı 10, Kasım 1952, s. 34-38.

149- M. Ş. E., "Hafız ” (Hikâye), Seçilmiş Hikâyeler, sayı 11, Aralık 1952, s. 11-16.

150- M. Ş. E., "Taş Havan ” (Hikâye), Seçilmiş Hikâyeler, sayı 5, cilt 6, s. 9-15.

151- M. Ş. E., "Bu Sıska Karı ” (Hikâye), Seçilmiş Hikâyeler, sayı 5, cilt 6, s. 27-33.

152- M. Ş. E., "Hamit İçin Bir Yazı” (Hikâye), Seçilmiş Hikâyeler, sayı 5, cilt 6, s. 47-56.

153- M. Ş. E., “Karısının Kocası ”12 (Hikâye), Seçilmiş Hikâyeler, sayı 5, cilt 6, s. 75-81.

154- M. Ş. E., "Kelepir” (Hikâye), Seçilmiş Hikâyeler, sayı 6, cilt 6, s. 14-21.

155- M. Ş. E., "Sahan Külbastısı” (Hikâye), Seçilmiş Hikâyeler, sayı 12, Ocak 1953, s. 14-18.

156- M. Ş. E., "Yeni Vali ” (Hikâye), Seçilmiş Hikâyeler, sayı 13, Şubat 1953, s. 11-14/17-18.

157-M.Ş.E., “Gençlik” (Hikâye), Yenilik, sayı 7, 15 Haziran-15 Temmuz 1953.

158-M.Ş.E., "Sinema” (Hikâye), Yenilik, sayı 29-5, 1 Mayıs 1955, s. 14-17.

159- Memduh Şevket Esendal, "Sorumlu” (Hikâye), Dost, sayl 1, cilt 1, Ekim 1957, s. 24-30.

\footnotetext{
12 Bu hikaye daha sonra 1976 yılında Yusuf Kurçenli tarafından TRT yapımı olarak sinemaya aktarılmıştır. Filmin senaristi ise Selim İleri'dir. 
160-Memduh Şevket Esendal, “Çolak” (Hikâye), Dost, sayı 2, cilt 1, Kasım 1957, s. 15-18.

161- Memduh Şevket Esendal, "Nazırın Odacısı" (Hikâye), Dost, sayı 8, cilt 2, Mayıs 1958, s. 5-7.

162-Memduh Şevket Esendal, "Bana Kaçık Derler” (Hikâye), Dost, sayı 32, cilt 7, Mayıs 1960, s. 5-7.

163-M.Ş.E., Bu Sıska Karı (Hikâye), Milliyet Sanat Dergisi, 1 Mayıs 1983, s. 27.

\section{Sonuç}

Yazarlık hayatına 1902 yılında Musavver Fen ve Edeb mecmuasıyla başlayan Esendal'ın edebi hayatı 1952 yllında Seçilmiş Hikayeler'le son bulmuştur. Çeşitli dergi ve gazetelerde hikâyeler neşreden Esendal'ın yazarlık hayatı birçok gelgitlere sahne olmuştur. Onun edebiyatçı kişiliğgi siyasetçi kimliğiyle yan yana devam etmiş olmasına rağmen kendisi bu ikisinin birbirinden ayrılması için çok çaba sarf etmiştir. Edebi hayatını siyasi hayatının etkisinden uzak tutmaya çalışmış fakat bunda başarılı olamamıştır.

Elçilik görevleri nedeniyle yurtdışında bulunduğu uzun dönemler boyunca onun ismini gazete ve dergi sütunlarında görmek mümkün değildir. Ülkede bulunduğu dönemlerde de sürekli siyasi çevreler içerisinde yer alması istemese de onu iktidar ve iktidar çevresindeki edebi kanonlara mahkum etmiştir. Siyasi hayatının düşüşe geçtiği dönemlerde de bu edebi kanonlar tarafından yok sayılmıştır. Ayrıca Esendal'ın sosyal, iktisadi ve siyasi görüşleri de onun hayatının sonlarında ve ölümünden sonra görmezden gelinmesine sebep olmuştur. Bundan dolayı onun hayatı ve eserleri edebiyat-siyaset ilişkisinin boyutlarını daha net ortaya kayabileceği gibi edebi kanonların edebiyatımızı nasıl etkilediğini göstermesi bakımından önem arz etmektedir.

Bu bibliyografya sayesinde Esendal'ın elli yıllık edebi hayatının tam bir hasılası ortaya çıkarılmaya çalışılmıştır. Ayrıca bu çalışma önemli bir hikâyeci olmasına rağmen yıllarca görmezden gelinen Memduh Şevket Esendal'ın hatırlanmasına ve araştırmacıların dikkatini çekmesine vesile olacaktır.

\section{Kaynakça}

Adıvar, H. E. (2016). Sonsuz Panayır. İstanbul: Can Yayınları.

Alangu, T. (1968). Cumhuriyet'ten Sonra Hikaye ve Roman 1. İstanbul.

Ayaşlı, M. (2016). Geniş Ufuklara ve Yabancı İklimlere Doğru. İstanbul: Timaş Yayınları.

Beyaz, Y. (2018). Göldedeki Adam Memduh Şevket Esendal. İstanbul: Pınar Yayınları.

Çetişli, İ. (2004). Memduh Şevket Esendal. Ankara: Akçă̆ Yayınları.

Esendal, A. (1972). Bir Açlklama, Türk Dili. (251), 427.

Esendal, M.Ş. (2001). Kızıma Mektuplar. Ankara: Bilgi Yayınevi.

Esendal, M.Ş. (2003). Oğullarıma Mektuplar. Ankara: Bilgi Yayınevi.

Kolcu, A. (2004). Musavver Fen ve Edeb Mecmuası (Yayımlanmamış Yüksek Lisans Tezi, Erzurum: Atatürk Üniversitesi Sosyal Bilimler Enstitüsü).

Memduh Şevket. (3 Muharrem 1328-15 Kanunisani 1910). Geçen Lakırdılar. Tanin, s. 2.

Memduh Şevket. (17 Muharrem 1328-29 Kanunisani 1910). Geçen Lakırdılar. Tanin, s. 2.

Türkarslan, H. (2011). Vakit Gazetesi’nde Edebi ve Kültürel Hareketlilik (29 Ekim 1923-4 Ekim 1926)

(Yayımlanmamış Yüksek Lisans Tezi, Ankara: Gazi Üniversitesi Sosyal Bilimler Enstitüsü). 
Uyguner, M. (1991). Memduh Şevket Esendal. Ankara: Bilgi Yayınevi.

Yund, K. (Haziran 1972). Esendal'dan Anılar. Türk Dili. (249), 239. 